\title{
Bacteriological Profile of Community Acquired Pneumonia in a Tertiary Care Hospital
}

\author{
Archana Choure Chintaman*, Dnyaneshwari P. Ghadage and Arvind V. Bhore
}

SKNMC and GH, Pune, India

*Corresponding author

\begin{tabular}{|c|c|}
\hline & A B S T R A C T \\
\hline $\begin{array}{l}\text { Ke y w o r d s } \\
\text { Bacterial, } \\
\text { Community } \\
\text { acquired } \\
\text { pneumonia, } \\
\text { Hospitalized } \\
\text { patients. }\end{array}$ & \multirow{3}{*}{$\begin{array}{l}\text { Pneumonia occurring in a hospital or long term care facilities remains a common and } \\
\text { serious illness, despite the availability of potent new antibiotics and effective vaccines. } \\
\text { Aim of the study is to identify and isolate the bacteria causing pneumonia in hospitalized } \\
\text { patients. The present study was carried out from June } 2014 \text { to July } 2015 \text { in the department } \\
\text { of microbiology, Smt. Kashibai Navale Medical College and General Hospital, Pune. Total } \\
920 \text { blood, sputum and BAL (Broncho Alveolar Lavage) samples were received during } \\
\text { this period. All were processed for identification of bacteria as per standard } \\
\text { microbiological procedures. 1) Out of } 920 \text { samples } 280(30.43 \%) \text { grew the pathogenic } \\
\text { bacteria. 2) Among } 280 \text { isolates Klebsiella pneumoniae } 42.85 \% \text { was the most common } \\
\text { followed by Pseudomonas aeruginosa } 28.57 \% \text {, Staphylococcus aureus } 21.43 \% \text { and } \\
\text { Streptococcus pneumoniae 7.14\%. Gram negative bacilli predominate in the } \\
\text { bacteriological profile of pneumonia. }\end{array}$} \\
\hline Article Info & \\
\hline $\begin{array}{l}\text { Accepted: } \\
\text { 02 March } 2017 \\
\text { Available Online: } \\
10 \text { April } 2017\end{array}$ & \\
\hline
\end{tabular}

\section{Introduction}

Community Acquired Pneumonia (CAP) occurring in a hospital or long term care facilities remains a common and serious illness, despite the availability of potent new antibiotics and other effective therapies (Aroma et al., 2006). CAP is defined as pulmonary infiltration of the lung revealed by radiographic examination at the time of admission, including at least two of the following

1. Fever (temp $>37.8^{0} \mathrm{C}$ )

2. Production of purulent sputum

3. Cough

4. Leucocytosis (WBC count >10000/ cumm $)^{1}$
The etiological agents of CAP are different in different countries. It varies with time and geographical distribution within the same country. Streptococcus pneumoniae is the most common etiological agent in United Kingdom, Europe, United States of America and Iraq. In India $S$. pneumoniae is most common organism in Delhi, Shimla and Mumbai whereas Pseudomonas aeruginosa in Ludhiana (Shah et al., 2010; Lode, 2007; Bansal et al., 2004).

CAP is diagnosed by physical examination, $\mathrm{X}$-ray and laboratory investigations. Invasive methods are the most effective methods for diagnosis of CAP but it has drawback of 
technical difficulty and sample contamination due to oropharyngeal secretions (Bansal et al., 2004; Peto et al., 2014). The present study was undertaken to determine the bacteriological profile of CAP.

The main aim of this study is to identify and isolate the bacteria causing community acquired pneumonia in hospitalized patients.

\section{Materials and Methods}

The present study was carried out from June 2014 to July 2015 in the department of microbiology, Smt. Kashibai Navale Medical College and General Hospital, Pune. Total 920 blood, sputum and BAL (Broncho Alveolar Lavage) samples were received during this period (Table 1). All were processed for identification of bacteria as per standard microbiological procedures.

\section{Inclusion criteria}

For CAP clinically diagnosed and radiologically diagnosed adult cases of pneumonia were included.

All specimens were collected before administration of antibiotics and processed as per standard bacteriological techniques.

\section{Exclusion criteria}

Any patient of pediatric age group.

Cases of tuberculous pneumonia screened by Zeihl Neelson stain.

\section{Processing}

Sputum and Broncho Alveolar Lavage- Gram and $\mathrm{ZN}$ staining were performed. In gram staining Murray Washington's grading system was followed for culturing (Koneman et al., 2005). ZN stain was used to rule out $\mathrm{TB}$ cases. Blood- five to ten $\mathrm{ml}$ blood was collected in blood culture bottle before administration of antibiotics. All samples were inoculated on Blood, Chocolate and MacConkey's agar. All media were incubated at $37^{\circ} \mathrm{C}$ for 18 to $24 \mathrm{hrs}$. The bacterial growth was subjected to gram staining and biochemical reactions for identification (Koneman et al., 2007; Collee et al., 2012).

\section{Results and Discussion}

Out of 920 samples $280(30.43 \%)$ grew the pathogenic bacteria (Fig. 1). Sputum Gram stain is necessary to check suitability for culture; in our study we found $21.33 \%$ saliva samples. So quality of specimen has an important role in diagnosis of CAP. Bacterial etiology was found only in $30.43 \%$ cases. Our results are consistent with Shah et al., (2010) (29\%), but studies of Bansal et al., (2004) (75.6\%) and Mythri et al., (2013) (72\%) were having high isolation rate. Low rate of isolation could be due to quality of sputum, prior antibiotics and lack of availability of serological methods for the detection of Mycoplasma, Chlamydia, Legionella and viruses. Percentage also depends on total number of samples tested we have a huge number compared to other studies, so may be affecting the positivity percentage.

In our study, total of $84.28 \%$ cases were above 50 years age with male preponderance while Shah et al., (2010) reported that $67 \%$ of cases are above 50 age group. Obero et al., (2007) found that the mean age group suffering from CAP was 40 years (Fig. 2). So increasing age may be one of the risk factor for pneumonia. Other risk factors are smoking, alcoholism, COPD, diabetes and chronic kidney disease (Ramana et al., 2013).

Among 280 isolates Klebsiella pneumoniae $42.85 \%$ (120/280) was the most common followed by Pseudomonas aeruginosa $28.57 \%$ (80/280), Staphylococcus aureus $21.43 \%(60 / 280)$ and Streptococcus pneumoniae $7.14 \%$ (20/280) (Table 2). 
Table.1 Distribution of samples

\begin{tabular}{|l|l|}
\hline SAMPLE & NO. \\
\hline BLOOD & 200 \\
\hline SPUTUM & 480 \\
\hline BAL & 240 \\
\hline TOTAL & 920 \\
\hline
\end{tabular}

Table.2 Culture results

\begin{tabular}{|l|l|}
\hline BACTERIA NAME & NUMBER \\
\hline Klebsiella pneumoniae & 120 \\
\hline Pseudomonas aeruginosa & 80 \\
\hline Staphylococcus aureus & 60 \\
\hline Streptococcus pneumoniae & 20 \\
\hline Total & 280 \\
\hline
\end{tabular}

Fig.1 Sex distribution of cases

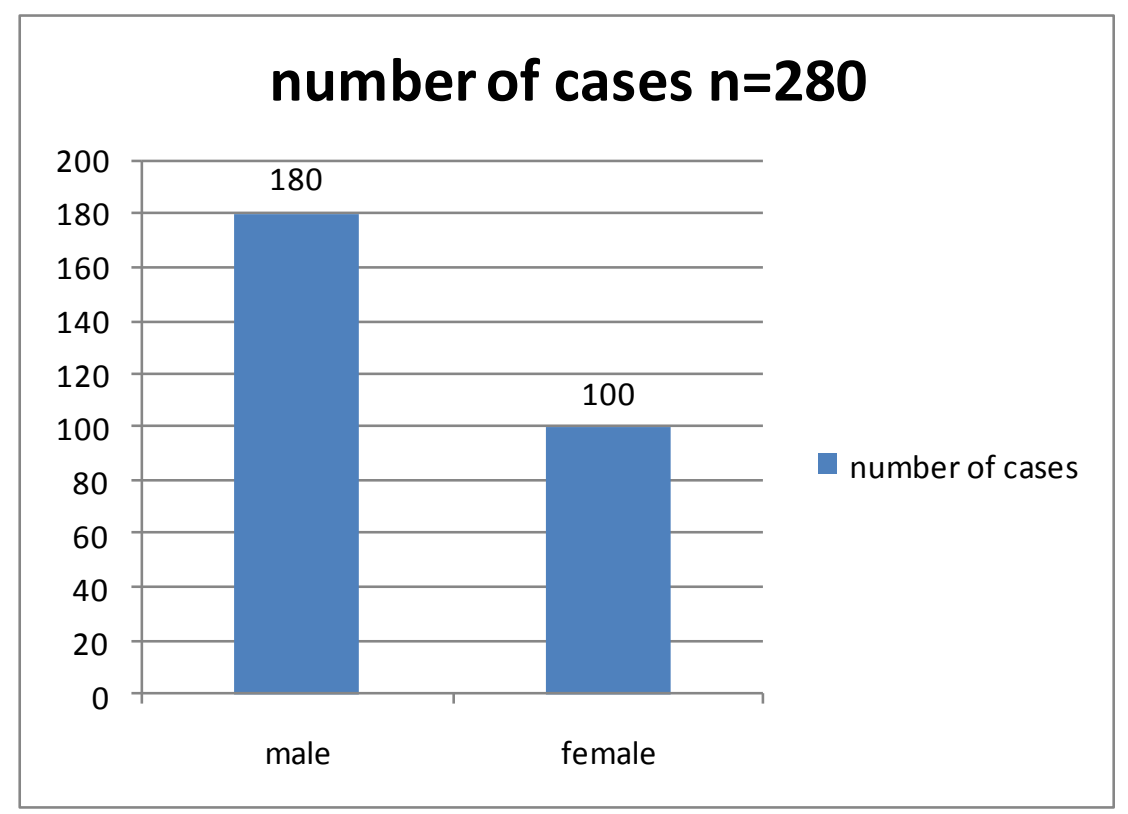


Fig.2 Age wise distribution of cases

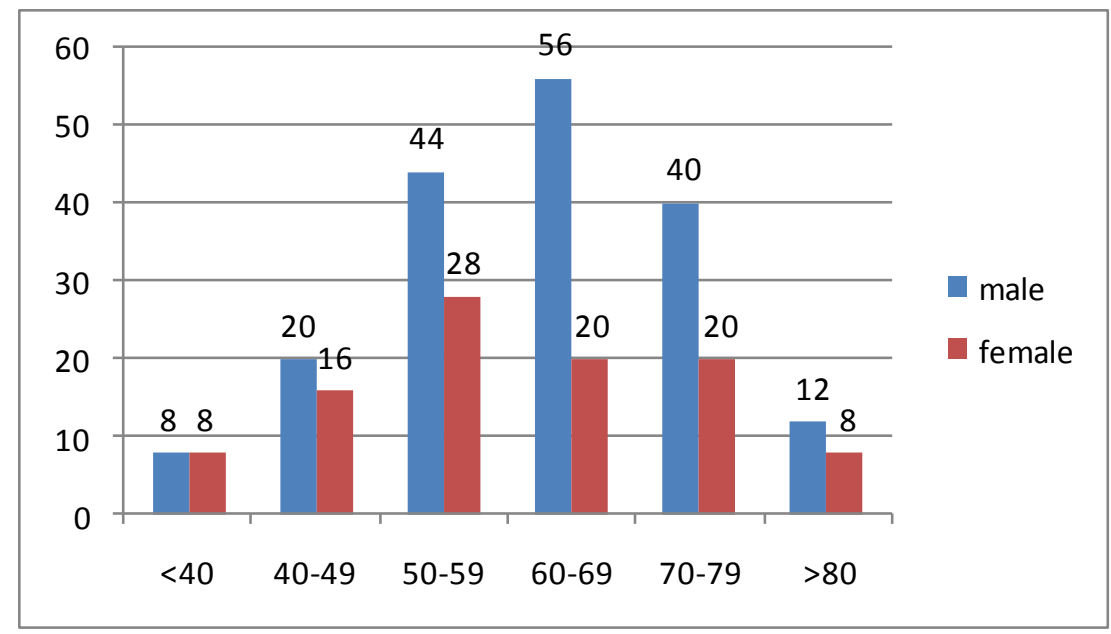

Fig.3 Distribution of bacteria causing pneumonia

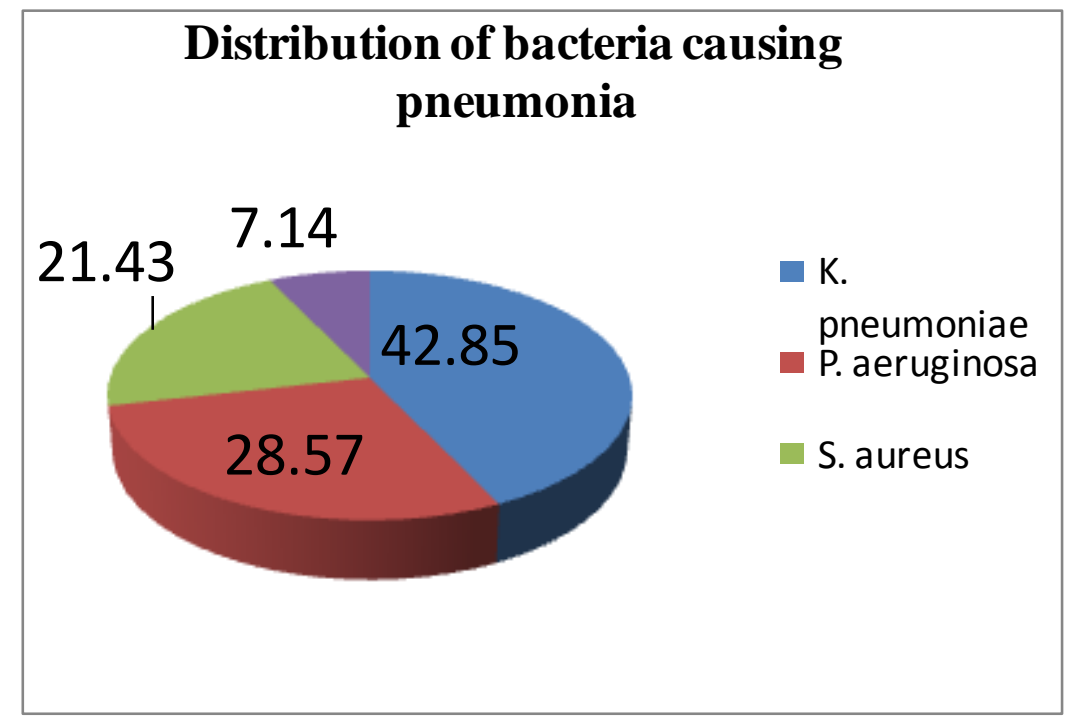

Shah et al., (2010) reported Pseudomonas aeruginosa $(34.48 \%)$ as the most common pathogen followed by Staphylococcus aureus (24.14\%). Mythri et al., (2013) reported that the most common pathogen was Klebsiella spp followed by $S$. pneumoniae and $P$. aeruginosa. Ramana et al., (2013) revealed that Klebsiella pneumoniae (45.1\%) was the predominant followed by Citrobacter freundii (12.9\%), Pseudomonas aeruginosa (9.6\%) and Staphylococcus aureus (9.6\%).
Oberoi et al., (2006) have reviewed three decades scenario for culture positive pneumonia cases in India. They have reported higher incidence of gram negative organisms among culture positive pneumonia. In our study we have also seen the predominance of gram negative organisms (Fig. 3).

In conclusion Gram negative bacilli predominate in the bacteriological profile of pneumonia. In our tertiary care hospital 
Klebsiella pneumoniae was the most common pathogen causing CAP followed by Pseudomonas aeruginosa. There is need to perform other serological tests to identify atypical and viral pathogens in all patients admitted with CAP. Identification of etiological agent in CAP is very important to start the appropriate antimicrobial drug. It is essential because indiscriminate use of antibiotics had led to wide spread emergence of multidrug resistant pathogens. The profile of bacterial agents varies with the geographical area, so it is necessary to do the surveillance to find out the exact causative agents. This will help to form the proper antibiotic policy for that particular hospital, which in turn will reduce the patient mortality and morbidity.

\section{References}

Aroma Oberoi, Aruna Aggarwal. 2006. Bacteriological Profile, Serology and Antibiotic Sensitivity Pattern of Microorganisms from Community Acquired Pneumonia. J.K. Sci., 8(2): 79-82.

Bansal, S,. Kashyap, S., Pal, L.S., Goel, A. 2004. Clinical and Bacteriological profile of community acquired pneumonia in Shimla, Himachal Pradesh. Indian J. Chest Dis. Allied Sci., 46: 17-22.

Collee, J.G., Marr, W., Fraser, A.G. 2012. Mackie and McCartney's Practical Medical Microbiology. $14^{\text {th }}$ edition. New Delhi: Elsevier; p95-111.
Koneman, W.K., Allen, S.D., Janda, W.M., Schreckenberger, P.C., Propcop, G.W., Woods, G.L., et al. 2005. Colour Atlas and Textbook of Diagnostic Microbiology, $6^{\text {th }}$ ed. Lippincott-Raven; p624-62.

Lode, H.M. 2007. Managing communityacquired pneumonia. E European perspective. Respir. Med., 101: 186473.

Mythri, S., Nataraju, H.V. 2013. Bacteriological profile of community acquired pneumonia. IOSR J. Dent. Med. Sci., 12(2): 16-19.

Peto, L., Nadjim, B., Horby, P., Dieu Ngan, T.T., Doorn, R.V., Kinh, N.V., et al. 2014. The bacterial aetiology of adult community-acquired pneumonia in Asia: a systematic review. Trans $R$ Soc. Trop. Med. Hyg., 108: 326-337.

Ramana, K.V., Anand Kalaskar, Mohan Rao, and Sanjeev D. Rao. 2013. "Aetiology and Antimicrobial Susceptibility Patterns of Lower Respiratory Tract Infections (LRTI's) in a Rural Tertiary Care Teaching Hospital at Karimnagar, South India." American J. Infect. Dis. Microbiol., 1, no. 5: 101-105. doi: 10.12691/ajidm-1-5-5.

Shah, B.A., Singh, G., Naik, M.A., Dhobi, G.N. 2010. Bacteriological and clinical profile of community acquired pneumonia in hospitalized patients. Lung India, 27(2): 54-57.

\section{How to cite this article:}

Archana Choure Chintaman, Dnyaneshwari P. Ghadage and Arvind V. Bhore. 2017. Bacteriological Profile of Community Acquired Pneumonia in a Tertiary Care Hospital. Int.J.Curr.Microbiol.App.Sci. 6(4): 190-194. doi: https://doi.org/10.20546/ijcmas.2017.604.022 